\title{
HUBUNGAN LINGKAR PINGGANG DENGAN KADAR KOLESTEROL LDL PASIEN PENYAKIT JANTUNG KORONER DI RUANG ICCU RSUP SANGLAH DENPASAR
}

\author{
I Gusti Ayu Ari Rasdini \\ Jurusan Keperawatan Poltekkes Denpasar Bali \\ Email: rasdiniari@yahoo.co.id
}

\begin{abstract}
Abstrack: Relationship of Waist Circumference with LDL Cholesterol Levels Coronary Heart Disease Patients in the ICCU RSUP Sanglah Denpasar. Mortality due to coronary heart disease is increasing. The main cause is obesity. Abdominal fat accumulation is known as central obesity or visceral obesity is associated with coronary heart disease. The aim of research to determine the relationship of waist circumference and LDL cholesterol levels in patients with coronary heart disease ICCU room Sanglah Hospital. The method used analytic observational with cross sectional approach. Samples using non-probability sampling with accidental sampling technique, a sample of 30 people. The results of the research sample characteristics 30 male sex. The average large waist circumference $94.03 \mathrm{~cm}(63.3 \%)$ in the category of LDL cholesterol levels $\geq 130 \mathrm{mg} / \mathrm{dl}$. Based on the results of correlation between waist circumference and levels of LDL cholesterol obtained 0.631 probability value that indicates the relationship is between waist circumference and LDL cholesterol levels.
\end{abstract}

Keywords: Waist circumference, LDL Cholesterol, Coroner Heart Disease.

\begin{abstract}
Abstrak: Hubungan Lingkar Pinggang dengan Kadar Kolesterol LDL Pasien Penyakit Jantung Koroner di Ruang ICCU RSUP Sanglah Denpasar. Angka kematian akibat penyakit jantung koroner semakin meningkat. Penyebab utama adalah obesitas. Penimbunan lemak perut dikenal dengan obesitas sentral atau obesitas visceral yang berkaitan dengan penyakit jantung koroner. Tujuan penelitian untuk mengetahui hubungan lingkar pinggang dengan kadar kolesterol LDL pasien penyakit jantung koroner di Ruang ICCU RSUP Sanglah Denpasar. Metode yang digunakan observasional analitik dengan pendekatan cross sectional. Sampel menggunakan tehnik non probabilitysampling yaitu accidental sampling, sampel 30 orang. Hasil penelitian diperoleh karakteristik sampel 30 orang berjenis kelamin laki-laki. Rata-rata besar lingkar pinggang 94,03 $\mathrm{cm}(63,3 \%)$ dalam kategori kadar kolesterol LDL $\geq 130 \mathrm{mg} / \mathrm{dl}$. Berdasarkan hasil uji korelasi antara lingkar pinggang dengan kadar kolesterol LDL didapatkan nilai probabilitas 0,631 yang menunjukkan hubungan yang sedang antara lingkar pinggang dengan kadar kolesterol LDL.
\end{abstract}

Kata kunci: Lingkar pinggang, LDL Kolesterol, Penyakit Jantung Koroner

Di Indonesia, angka kematian akibat Penyakit Jantung Koroner (PJK) mencapai 26\%. Berdasarkan hasil Survei Kesehatan Rumah Tangga Nasional (SKRTN), dalam 10 tahun terakhir angka tersebut terus mengalami peningkatan. Angka kematian akibat PJK diperkirakan mencapai 53,5 per 100.000 penduduk di Indonesia (Siburian, 2001).

Penyakit jantung koroner adalah penyakit yang ditandai dengan penimbunan abnormal lipid atau bahan lemak dan jaringan fibrosa di dinding pembuluh darah yang mengakibatkan perubahan struktur dan fungsi arteri serta penurunan aliran darah ke jantung (Brunner dan Suddarth, 2002). Jenis lipid tersebut antara lain kolesterol, trigliserida, fosfolipid dan asam lemak bebas. Keempat unsur lemak ini akan diserap dari usus dan masuk ke dalam darah. Kolesterol dan unsur lemak lain tidak larut dalam darah. Agar dapat diangkut dalam aliran darah, kolesterol bersama dengan unsur lemak lain harus berikatan dengan protein untuk membentuk senyawa yang larut dan disebut dengan lipoprotein. Bila kolesterol sedikit berikatan dengan lipoprotein disebut LDL/ low density lipoprotein. LDL inilah yang menyebabkan arterosklerosis pada pembuluh darah koroner (Almatsier, 2005).

Penyebab utama peningkatan kolesterol LDL dalam darah adalah asupan lemak jenuh yang tinggi dan kegemukan atau obesitas (Almatsier, 2007). Obesitas adalah keadaan ditemukannya kelebihan lemak dalam tubuh, terbagi menjadi obesitas general dan obesitas sentral. Penimbunan lemak dalam perut yang dikenal dengan obesitas sentral atau obesitas visceral lebih berkaitan dengan penyakit jantung 
koroner. Dibandingkan dengan lemak subkutan atau lemak tubuh total (obesitas general), lemak viseral (obesitas sentral) lebih kuat hubungannya dengan kelainan sindroma metabolik. Adiposit jaringan lemak ini adalah adiposit berukuran besar, peka terhadap kerja antilipolisis sehingga lebih mudah dilipolisis yang menyebabkan peningkatan kadar asam lemak bebas (Jalal dkk, 2010).

Lemak visceral merupakan sumber asam lemak bebas yang langsung menuju hati melalui vena porta. Terlebih lagi bahwa jaringan lemak viseral ini relatif resisten terhadap kerja insulin yang ditunjukkan dengan relatif tidak terhambatnya lipolisis jaringan ini pada fase setelah makan padahal konsentrasi insulin pada waktu itu meningkat (Aminuddin, 2010). Hal tersebut meningkatkan proses glukoneogenesis dan juga menghambat ambilan serta penggunaan glukosa di otot. Akumulasi trigliserida di hati dan di otot akan mengakibatkan resistensi insulin (Jalal dkk, 2010). Glukoneogenesis yang meningkat menyebabkan jumlah protein yang tersisa sedikit sementara terjadi peningkatan pembentukan kolesterol di hati, sehingga kolesterol yang terbentuk sedikit berikatan dengan lipoprotein dan mengakibatkan terjadi peningkatan kadar kolesterol LDL (Murray, 2003).

Obesitas sentral dapat ditentukan melalui ukuran antropometri yaitu lingkar pinggang, dan kriteria untuk Asia Pasifik termasuk Indonesia yaitu $\geq 90 \mathrm{~cm}$ untuk pria, dan $\geq 80 \mathrm{~cm}$ untuk wanita. Lingkar pinggang dikatakan sebagai indeks yang berguna untuk menentukan obesitas sentral dan komplikasi metabolik yang terkait. Lingkar pinggang berkorelasi kuat dengan obesitas sentral dan risiko kardiovaskular. Selain itu, cadangan lemak biasanya paling banyak terkonsentrasi di perut. Oleh karena itu, lingkar pinggang terbukti dapat mendeteksi obesitas sentral dan sindroma metabolik dengan ketepatan yang cukup tinggi (Jalal dkk, 2010).

Semakin banyak timbunan lemak di rongga perut akan diikuti dengan tingginya kolesterol LDL dan kolesterol total. Secara sederhana dapat dikatakan bahwa semakin tinggi kadar kolesterol LDL semakin panjang ikat pinggang seseorang. Dengan kata lain, kadar kolesterol LDL dan kadar kolesterol total berbanding lurus dengan panjang lingkar pinggang (Semiardji, 2010). Rumusan masalah dalam penelitian ini adalah sebagai berikut : "Apakah ada hubungan antara lingkar pinggang dengan kadar kolesterol LDL pasien penyakit jantung koroner di Ruang ICCU RSUP Sanglah Denpasar?"
Tujuan penelitian ini adalah ingin mengetahui hubungan lingkar pinggang dengan kadar kolesterol LDL pasien penyakit jantung koroner di Ruang ICCU RSUP Sanglah Denpasar.

Menurut Girson (2010), ada beberapa faktorfaktor yang dapat menyebabkan bertambahnya lingkar pinggang, di antaranya:

\section{a. Gaya hidup.}

Pola makan yang tidak benar adalah penyebab utama bertambahnya lingkar pinggang. Kebiasaan hidup yang kurang aktivitas dan konsumsi makanan yang berlebih dari energi yang dibutuhkan, membuat sisa kalori disimpan sebagai lemak dalam sel-sel lemak. Lemak menumpuk di seluruh tubuh, termasuk daerah perut, dan akan meningkat seiring bertambahnya berat badan dan gaya hidup yang buruk. Kalori berlebih ini tersimpan dalam banyak makanan rendah serat maupun tinggi lemak jenuh. Makanan tersebut seperti olahan daging, beberapa jenis margarin, goreng-gorengan terutama dengan minyak goreng yang digunakan berulang, sayur kalengan, beberapa makanan ringan, kue, makanan junk food, dan masih banyak lagi.

\section{b. Usia}

Secara alami, aktivitas akan berkurang seiring dengan pertambahan usia. Bukan hanya aktivitas yang berkurang, massa otot pun akan berkurang ketika latihan sudah kurang intens. Ini semua menyebabkan penambahan berat badan dan lingkar perut, apalagi aktivitas yang berkurang tidak diimbangi dengan mengurangi asupan kalori. Hasilnya, semakin bertambah usia semakin bertambah lingkar pinggang.

\section{c. Gen dan jenis kelamin}

Seseorang dapat berkecenderungan menumpuk lemak di perut secara genetik. Namun, jika tidak mengalami pertambahan berat badan yang radikal, bagian tengah tubuh pun tidak akan berkembang pesat. Kebanyakan pria cenderung menyimpan lemak di perut atas dan panggul (bentuk tubuh apel), sehingga dikatakan pria lebih berpotensi memiliki perut buncit. Sedangkan sebagian besar wanita sebelum menopause cenderung menyimpan lemak di perut bawah, sisi paha, pinggul, dan pantat (bentuk tubuh seperti buah pir). Setelah menopause, lemak akan lebih banyak tersimpan di perut. Hal ini telah dikodekan dalam gen dan tidak dapat dikendalikan kemana lemak akan tersimpan. 


\section{d. Alkohol}

Mengkonsumsi alkohol terlalu banyak dapat menyebabkan tubuh kurang efisien dalam membakar lemak. Lemak pun semakin banyak tertimbun dalam tubuh seiring berjalannya waktu dan kebiasaan mengonsumsi alkohol yang terus.

\section{e. Hormon}

Peningkatan stres dalam kehidupan seharihari seperti kurang tidur, dapat menyebabkan lemak perut bertambah. Kondisi kurang tidur meningkatkan produksi hormon kortisol dalam otak dan ini meningkatkan penumpukan lemak perut.

\section{f. Lemak perut}

Setelah mengkonsumsi bahan makanan dengan kandungan karbohidrat, dihasilkan glukosa di dalam darah. Organ pankreas mengeluarkan insulin untuk membongkarnya menjadi energi yang dibutuhkan sel. Bila pembongkaran glukosa darah kurang optimal, misalnya karena berkurangnya efektivitas insulin oleh lemak dalam darah atau jumlah glukosa terlalu banyak, maka sisa glukosa tersebut akan tersimpan sebagai lemak dalam perut (visceral $f a t$ ). Efek langsung dari lemak dalam perut yang berlebih, menyebabkan seseorang menderita obesitas sentral.

Dampak lemak perut terhadap kolesterol LDL Abdominal fat mencakup visceral fat (meliputi organ dalam perut) dan subcutaneous fat (berada antara kulit dan dinding perut). Lemak yang terletak di belakang rongga perut disebut retroperitoneal fat, juga terhitung sebagai visceral fat (Siswanto, 2010). Lemak tubuh atau jaringan lemak berfungsi sebagai gudang penyimpanan energi yang berlebih. Jadi suatu waktu dapat digunakan bila tubuh kekurangan energi. Namun, penelitian menunjukkan bahwa sel-sel lemak, terutama sel abdominal fat ternyata bersifat aktif secara biologis. Selain itu, tumpukan lemak perut ini juga memproduksi beberapa hormon dan bahan kimia lain yang bisa mempengaruhi kesehatan (Siswanto, 2010).

\section{METODE PENELITIAN}

Penelitian observasional analitik adalah jenis penelitian yang meneliti hubungan antar variabel (Setiadi, 2007). Jenis penelitian yang digunakan dalam penelitian ini adalah penelitian observasional analitik karena meneliti hubungan antar variabel, yaitu hubungan antara lingkar pinggang dengan kadar kolesterol LDL pada pasien penyakit jantung koroner. Desain penelitian yang digunakan adalah studi korelasi. Dalam penelitian ini perlu dilakukan analisis terhadap data yang dikumpulkan untuk mengetahui seberapa besar hubungan antar variabel yang ada.

Metode pendekatan cross sectional yaitu variabel bebas (sebab) dan variabel terikat (akibat) yang terjadi pada subyek penelitian diukur dan dikumpulkan secara simultan, sesaat atau satu kali saja dalam satu kali waktu (dalam waktu yang bersamaan), penelitian ini tidak ada follow up (Setiadi, 2007). Metode pendekatan yang digunakan dalam penelitian ini adalah cross sectional.

Sampel penelitian adalah sebagian dari keseluruhan obyek yang diteliti dan dianggap mewakili seluruh populasi (Setiadi, 2007). Adapun yang menjadi sampel dalam penelitian ini adalah pasien penyakit jantung koroner di Ruang ICCU RSUP Sanglah Denpasar.

Sampel dalam penelitian ini adalah pasien PJK usia 30-60 tahun sebanyak 30 orang dengan tehnik consecutive sampling.

\section{HASIL}

Dalam penelitian ini yang menjadi sampel adalah pasien penyakit jantung koroner yang di rawat inap di ICCU RSUP Sanglah Denpasar dengan pemilihan sampel menggunakan accidental sampling. Besar sampel yang diperoleh sebanyak 30 orang yang telah memenuhi semua kriteria penelitian. Adapun karakteristik sampel yang telah diteliti sebagai berikut :

\section{a. Karakteristik sampel berdasarkan jenis kelamin}

Sesuai dengan penelitian yang telah dilakukan, diperoleh data bahwa dari 30 sampel, seluruh sampel berjenis kelamin laki-laki 30 orang $(100 \%)$.

\section{b. Karakteristik sampel berdasarkan umur}

Tabel 1. Karakteristik Sampel berdasarkan Umur

\begin{tabular}{ccc}
\hline Rentang Umur & n & $\%$ \\
\hline $30-39$ th & 2 & 7 \\
\hline $40-49$ th & 6 & 20 \\
\hline $50-59$ th & 12 & 40 \\
\hline $60-69$ th & 10 & 33 \\
\hline Jumlah & 30 & 100 \\
\hline
\end{tabular}


Dari tabel di atas, sebagian besar responden dengan umur $40-49$ tahun, 12 orang $(40 \%)$.

c. Karakteristik sampel berdasarkan

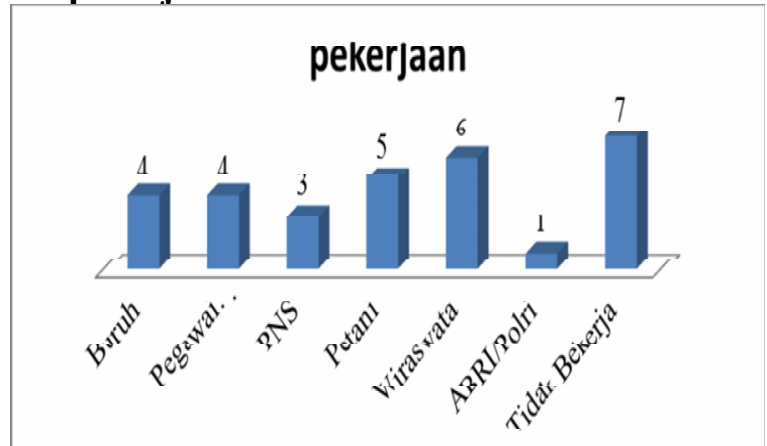

Gambar 1. Karakteristik Sampel berdasarkan Pekerjaan di Ruang ICCU RSUP Sanglah Denpasar

Dari gambar 1 diketahui dari 30 sampel sebanyak 4 orang bekerja sebagai buruh, 4 orang sebagai pegawai swasta, 3 orang sebagai PNS, 5 orang sebagai petani, 6 orang sebagai wiraswasta, 1 orang sebagai ABRI/Polri, dan 7 orang sudah tidak bekerja.

\section{Hasil Pengamatan}

Alat pengumpulan data yang digunakan dalam penelitian ini adalah pita pengukur. Selain itu juga menggunakan lembar pengumpulan data dan alat tulis untuk mendokumentasikan hasil pengukuran. Data yang sudah didapatkan tersebut kemudian diolah dan menghasilkan data sebagai berikut :

a. Deskripsi data lingkar pinggang pada pasien penyakit jantung koroner

Tabel 2. Deskripsi Data lingkar Pinggang

\begin{tabular}{lc}
\hline \multicolumn{1}{c}{ Data } & Nilai $(\mathrm{cm})$ \\
\hline Mean & 94,03 \\
Median & 92,50 \\
Modus & 88 \\
Std deviation & 7,557 \\
Minimum & 87 \\
Maximum & 127 \\
\hline
\end{tabular}

Dari tabel 2 diketahui bahwa rata-rata besar lingkar pinggang 94,03 cm, median 92,50 $\mathrm{cm}$, modus $88 \mathrm{~cm}$, standar deviation 7,557, lingkar pinggang paling kecil $87 \mathrm{~cm}$ dan paling tinggi $127 \mathrm{~cm}$. b. Deskripsi data kadar kolesterol LDL pada pasien penyakit jantung koroner

Tabel 3. Deskripsi Data Kadar Kolesterol LDL

\begin{tabular}{lc}
\hline \multicolumn{1}{c}{ Data } & Nilai $(\mathrm{mg} / \mathrm{dl})$ \\
\hline Mean & 138,41 \\
Median & 136,35 \\
Modus & 102,12 \\
Std deviation & 23,668 \\
Minimum & 102,12 \\
Maximum & 189,90 \\
\hline
\end{tabular}

Berdasarkan tabel 3 diperoleh data ratarata kadar kolesterol LDL 138,41 mg/dl, median $136,35 \mathrm{mg} / \mathrm{dl}$, modus $102,12 \mathrm{mg} / \mathrm{dl}$, standar deviasi 23,668 mg/dl, kadar kolesterol minimum $102,12 \mathrm{mg} / \mathrm{dl}$ dan kadar kolesterol maximum $189,90 \mathrm{mg} / \mathrm{dl}$.

Tabel 4. Distribusi Data Kadar Kolesterol LDL pada Pasien Penyakit Jantung Koroner

\begin{tabular}{ccc}
\hline $\begin{array}{c}\text { Klasifikasi kadar } \\
\text { kolesterol LDL }\end{array}$ & $\mathrm{n}$ & $\%$ \\
\hline$<100 \mathrm{mg} / \mathrm{dl}$ & 0 & 0,0 \\
\hline $100-129 \mathrm{mg} / \mathrm{dl}$ & 11 & 36,7 \\
\hline$\geq 130 \mathrm{mg} / \mathrm{dl}$ & 19 & 63,3 \\
\hline Jumlah & 30 & 100,0 \\
\hline
\end{tabular}

Pada tabel 4 tampak bahwa 11 orang $(36,7 \%)$ terkategori berada dalam klasifikasi kadar kolesterol LDL 100-129 mg/dl dan 19 orang $(63,3 \%)$ terkategori berada dalam klasifikasi kadar kolesterol LDL $\geq 130 \mathrm{mg} / \mathrm{dl}$.

\section{Analisa Data}

Sebelum data dianalisis dilakukan uji prasyarat (normalitas data) untuk mengetahui data berdistribusi normal. Uji normalitas data dilakukan dengan menggunakan uji kolmogrovsmirnov.

Tabel 5. Hasil Uji Normalitas Data

\begin{tabular}{ccc}
\hline $\begin{array}{c}\text { One sample } \\
\text { kolmogrov- } \\
\text { smirnov test }\end{array}$ & $\begin{array}{c}\text { Lingkar } \\
\text { Pinggang }\end{array}$ & $\begin{array}{c}\text { Kadar } \\
\text { Kolesterol } \\
\text { LDL }\end{array}$ \\
\hline Asymp.sig & 0,270 & 0,982 \\
\hline
\end{tabular}

Adapun dari uji tersebut diperoleh hasil untuk data lingkar pinggang didapatkan nilai probabilitas $0,270 \quad(>0,05)$ sehingga data berdistribusi normal. Untuk data kadar kolesterol LDL diperoleh nilai probabilitas $0,982(>0,05)$ sehingga data berdistribusi normal. 
Karena kedua data berdistribusi normal maka diuji dengan uji parametris yaitu korelasi Product Moment.

Tabel 6. Hasil Uji Korelasi Product Moment

\begin{tabular}{lc}
\multicolumn{1}{c}{ Uji korelasi } & Nilai probabilitas \\
\hline Lingkar pinggang & 0,631 \\
dengan kadar & \\
kolesterol LDL & \\
\hline
\end{tabular}

Sesuai dengan hasil uji korelasi pada tabel di atas, korelasi antara lingkar pinggang dan kadar kolesterol LDL adalah 0,631. Hasil tersebut menunjukkan hubungan yang sedang antara kedua variabel. Jadi, ada hubungan yang sedang antara lingkar pinggang dengan kadar kolesterol LDL pasien PJK.

\section{PEMBAHASAN}

Pada penelitian ini ditemukan pasien penyakit jantung koroner yang menjadi sampel semuanya berjenis kelamin laki-laki yaitu sejumlah 30 orang (100\%). Menurut Price (1994) yang menyebutkan bahwa laki-laki memiliki risiko lebih besar terkena serangan jantung dan kejadiannya lebih awal dari pada wanita. Morbiditas penyakit PJK pada laki-laki dua kali lebih besar dibandingkan dengan wanita dan kondisi ini terjadi hampir 10 tahun lebih dini pada laki-laki daripada perempuan. Wanita agaknya relatif kebal terhadap penyakit ini sampai setelah menopause, dan kemudian menjadi sama rentannya seperti pria. Efek perlindungan estrogen dianggap sebagai penjelasan adanya imunitas wanita pada usia sebelum menopause. Estrogen endogen bersifat protektif pada perempuan, namun setelah menopouse insiden PJK meningkat dengan pesat, tetapi tidak sebesar insiden PJK pada laki-laki.

Penelitian ini juga menemukan dari 30 responden terbanyak berada pada rentang umur 50-59 tahun sejumlah 12 orang (40\%). Pada pria insiden puncak manifestasi klinik PJK adalah pada usia 50-60 tahun, sedangkan pada wanita pada usia 60-70 tahun. Pada wanita PJK terjadi sekitar 10-15 tahun lebih lambat daripada pria dan risiko meningkat secara drastis setelah menopause. Ini berarti bahwa laki-laki mempunyai resiko PJK 2-3 kali lebih besar dari perempuan. Menurut Price (1994), kerentanan terhadap arterosklerosis koroner meningkat dengan bertambahnya usia. Penyakit yang serius jarang terjadi sebelum usia 50 tahun. Hubungan antara usia dan timbulnya penyakit jantung koroner mungkin hanya mencerminkan lama paparan yang lebih panjang terhadap faktorfaktor aterogenik.

Berdasarkan hasil penelitian didapatkan bahwa sebagian besar sampel sudah tidak bekerja yaitu sejumlah 7 orang. Latihan-latihan olahraga selama 30 menit setiap kali berlatih dengan intensitas sedang sudah dapat menurunkan risiko PJK. Latihan yang lebih keras dan dalam jumlah lebih banyak dapat lebih menurunkan risiko itu, meskipun penurunan risikonya tidak linier. Latihan olahraga dikatakan memiliki intensitas sedang apabila denyut nadinya mencapai kurang lebih $70-75 \%$ dari denyut nadi maksimal. Denyut nadi maksimal adalah 220 dikurangi umur dalam satuan tahun (Purdanto, 2008).

Pada penelitian ini ditemukan rata-rata besar lingkar pinggang 94,03 cm, median 92,50 $\mathrm{cm}$, modus $88 \mathrm{~cm}$, standar deviation 7,557, lingkar pinggang paling kecil $87 \mathrm{~cm}$ dan paling tinggi $127 \mathrm{~cm}$. Lingkar pinggang merupakan salah satu komponen sindrom metabolik. Asupan makanan berlebihan dan penurunan pengeluaran energi menimbulkan keseimbangan energi positif. Keseimbangan energi positif yang terjadi dari asupan makanan berlebihan terutama berasal dari kelebihan asupan energi dan sumber karbohidrat, sehingga terjadi akumulasi lemak berlebihan di jaringan adiposa abdominal yang akhirnya akan menambah ukuran lingkar pinggang atau obesitas sentral (Jalal dkk, 2006).

Dalam penelitian ini pula didapatkan data 11 orang $(36,7 \%)$ terkategori berada dalam klasifikasi kadar kolesterol LDL 100-129 mg/dl dan 19 orang $(63,3 \%)$ terkategori berada dalam klasifikasi kadar kolesterol LDL $\geq 130 \mathrm{mg} / \mathrm{dl}$. Bagi pasien penyakit jantung koroner kadar kolesterol LDL yang di atas $130 \mathrm{mg} / \mathrm{dl}$ tergolong sudah berbahaya, yang dapat memicu timbulnya penyakit lainnya. Dikaitkan dengan penyakit jantung koroner, maka peningkatan 1,0 persen risiko PJK untuk setiap kenaikan $1 \mathrm{mg} / \mathrm{dl}$ kolesterol LDL. Oleh karena itu, usahakan untuk selalu menjaga kadar kolesterol LDL (di bawah $130 \mathrm{mg} / \mathrm{dl}$ ) dan rendah kolesterol total (di bawah $200 \mathrm{mg} / \mathrm{dl}$ ).

Penelitian tentang hubungan lingkar pinggang dengan kadar kolesterol LDL pada pasien penyakit jantung koroner di Ruang ICCU RSUP Sanglah Denpasar juga menemukan hasil ada hubungan yang sedang antara lingkar pinggang dengan kadar kolesterol LDL. Hal ini dikarenakan kemungkinan pasien yang mendapatkan terapi obat penurun kolesterol. 


\section{SIMPULAN}

Berdasarkan penelitian yang dilakukan di Ruang ICCU RSUP Sanglah Denpasar, karakteristik sampel yang diperoleh adalah 30 orang berjenis kelamin laki-laki, 12 orang berumur antara 50-59 tahun, dan 7 orang sudah tidak bekerja.

Rata-rata besar lingkar pinggang $94,03 \mathrm{~cm}$, median $92,50 \mathrm{~cm}$, modus $88 \mathrm{~cm}$, standar deviation 7,557, lingkar pinggang paling kecil 87 $\mathrm{cm}$ dan paling tinggi $127 \mathrm{~cm}$.

Sebanyak 11 orang $(36,7 \%)$ terkategori berada dalam klasifikasi kadar kolesterol LDL
$100-129 \mathrm{mg} / \mathrm{dl}$ dan 19 orang $(63,3 \%)$ terkategori berada dalam klasifikasi kadar kolesterol LDL $\geq 130 \mathrm{mg} / \mathrm{dl}$.

Berdasarkan hasil uji korelasi antara lingkar pinggang dengan kadar kolesterol LDL didapatkan nilai probabilitas 0,631 yang menunjukkan hubungan yang sedang antara lingkar pinggang dengan kadar kolesterol LDL.

Disarankan kepada masyarakat khususnya yang mempunyai faktor risiko, untuk melakukan pemeriksaan sederhana yaitu dengan mengukur lingkar pinggang yang dapat digunakan sebagai indikator untuk mengukur kadar kolesterol LDL dalam darah.

\section{DAFTAR PUSTAKA}

Almatsier, S. 2005. Prinsip Dasar Ilmu Gizi. Jakarta: Gramedia Pustaka Utama. . 2007. Penuntun Diet. Jakarta: Gramedia Pustaka Utama.

Bull, E. 2007. Simple Guides Kolesterol. Jakarta: Erlangga.

Brunner dan Suddarth. 2002. Buku Ajar Keperawatan Medikal Bedah. Volume 2, Edisi 8. Jakarta: EGC.

Ganong, W.F. 2002. Fisiologi Kedokteran. Edisi 14. Jakarta: EGC.

Jalal, F dkk. 2010. Hubungan Lingkar Pinggang dengan Kadar Gula Darah, Trigliserida dan Tekanan Darah pada Etnis Minang di Kabupaten Padang Pariaman, Sumatera Barat, (online), Available: repository.unand.ac.id, (17 Desember 2010).

Murray, R.K. 2003. Biokimia Harper. Edisi 25. Jakarta: EGC.
Notoatmojo, S. 2002. Metodologi Penelitian Kesehatan. Jakarta: PT Rineka Cipta.

Nursalam. 2003. Konsep dan Penerapan Metodologi Ilmu Keperawataan. Edisi Pertama. Jakarta: Salemba Medika.

Piliang, S dkk. 1999. Buku Ajar Ilmu Penyakit Dalam. Jilid I, Edisi 3. Jakarta: Balai Penerbit FKUI.

Price, S.A. 1994. Patofisiologi Konsep Klinis Proses-Proses Penyakit. Volume 2, Edisi 4, Jakarta: EGC.

Setiadi, 2007. Konsep dan Penulisan Riset Keperawatan. Yogyakarta: Graha Ilmu.

Sherwood, L. 2001. Fisiologi Manusia: dari Sel ke Sistem. Jakarta: EGC.

Siburian, G. 2001. Epidemiologi PJK, (online), Available

http://himapid.blogspot.com/html, Desember 2010).

Sugiyono. 2010. Statistika untuk Penelitian. Bandung: Alfabeta. 